\title{
Students and their professional work in international perspective. Comparative analysis of social attitudes
}

\author{
Urszula Swadźba* \\ ${ }^{1}$ University of Silesia, Institute of Sociology, 40-007 Katowice, Poland
}

\begin{abstract}
Modern, global labour market requires a lot of skills and experience from employees. The young generation of V4 countries is the first generation whose reality is based on the laws of world capitalism. The paper discusses of students attitudes towards work, especially towards working abroad on a global labour market. The paper first presents the concept of attitudes, specially attitudes towards work. An analysis was carried out on the basis of empirical research, with the use of auditorium survey, within the framework of the Visegrad Standard Grant. The empirical research referred to in the text was conducted using the audit survey method at universities of four Visegrad countries - in Katowice (Poland), Nitra (Slovakia), Olomouc and Ostrava (Czech Republic) and Godollo (Hungary). In the paper three components attitudes toward work: cognitive, affective and behavioral will be analyzed. During the empirical analysis following questions will be answered: What is the students' knowledge about getting a job? What is the value of work in their lives? Are they going to emigrate abroad to look for a job and face global labour market? The conclusion will contain definitions of three types of students' attitude towards working on the global labour market (coherent, ambivalent and incoherent).
\end{abstract}

\section{Introduction}

The modern global economy requires creative and highly qualified employees. Especially young people are looking for a job that will fulfill their aspirations and ensure adequate earnings and decent life. That is why potential employees take into consideration migration abroad in their life plans [1,2]. This is one of the element of their outlook on life. Therefore our concerns will be the young generation of the countries of the Visegrad Group, specifically students. Thanks to the opening of the labour market in the European Union countries, it is a generation that can be a part of this market. [3].

The aim of this article is an analysis of three main components of students attitudes towards work, especially towards working abroad on a global labour market. During the analysis following questions will be answered: What is the students' knowledge about getting a job? What is the value of work in their lives? Are they going to emigrate abroad to

\footnotetext{
*Urszula.swadzba@us.edu.pl
} 
look for a job and face global labour market? The differences between young generation in certain countries will be pointed out. In the summary similarities and differences in attitudes of young generation V4 towards work will be presented.

\section{Literature review}

The issue of social attitudes is very often made by sociologists $[4,5,6]$. It often applies to attitudes towards work, especially professional work [7]. However, researchers rarely have a possibility to make international comparisons based on empirical research, which are uniform and conducted at the same time.

The concept of social attitude has appeared in sociology in the works of Florian Znaniecki. [8]. This concept has also been discussed in American sociology [9]. In Polish sociology it has been undertaken by Stanisław Ossowski, Stefan Nowak [10, 11]. For this article following Nowak's definition has been adopted: “The attitude of a man towards certain object is the whole of relatively permanent dispositions for an assessment of this object and emotional reactions to it and alternatively what also follows it is belief about the nature and properties of this object and relatively permanent dispositions to behaviour towards this object"[11]. In practice, adopting such definition means that we think about permanent disposition of a person towards a certain action. The attitude features so-called components: cognitive, emotional-evaluative (so-called affective) and behavioural (also called functional). Ossowski, similarly to Rokeach distinguish three components: cognitive component, which represent person knowledge in different level of certainty of what is real, good and desirable or what is false, wrong and undesirable in the subject matter of attitude; then affective component, which contains positive and negative feelings towards the subject matter of attitude; and behavioral component, because predisposition to reacting leads to action, when there is an update or reference to particular subject matter of attitude $[9,11]$.

The attitudes towards work, especially professional work, of young generation from Visegrad Group countries are going to be the subject matter of our analysis. Following analysis in only the part of a bigger research project, which concerns economic awareness. ${ }^{\dagger}$ It is defined in the following way: "It's a way of thinking and the attitude of man to economic reality. The economic awareness should include such elements as economic knowledge, value system and economic aspirations, work and entrepreneurship, the attitude towards wealth and poverty, attitude towards money and thriftiness, and consumption" [12]. One of the element of economic awareness is work. Work in theoretical concepts is most frequently presented as a human activity that converts the external world.

The following components of attitude towards work and professional career will be a subject matter of our analysis: cognitive component, that is knowledge about the possibilities of employment on the labour market after graduation, then affective component, that is placing work in the system of values. Behavioural component of attitudes towards work, which concerns certain behaviour towards professional work (undertaking work during studies) and potential behaviour towards placing yourself on the global labour market and carrying out professional work.

The attitudes towards professional work are a result of not only personal motives, but they depend on the requirements and demand on the labour market. In the Visegrad Group countries problems with the functioning of the labour market (unemployment, level and quality of employment, wages, employment service) are one of the most difficult to solve $[13,14,3]$. There is no place for detailed analysis about labour markets of these countries in

\footnotetext{
$\dagger$ The empirical analysis is part of the Visegrad Standard Grant: "The economic awareness of the young generation of Visegrad countries" no. 21420008 (2015-2016).
} 
our article, but short description includes the rate of unemployment, which are the most important factors illustrating the state of the labour market.

Table 1. The unemployment rate in Poland, Czech Republic, Slovakia and Hungary 2004-2015 (\%):

\begin{tabular}{|c|c|c|c|c|c|c|c|c|c|c|c|c|}
\hline \hline Country & 2004 & 2005 & 2006 & 2007 & 2008 & 2009 & 2010 & 2011 & 2012 & 2013 & 2014 & 2015 \\
\hline \hline Poland & 19,1 & 17,9 & 13,9 & 9,6 & 7,1 & 8,1 & 9,7 & 9,7 & 10,1 & 10,5 & 9,2 & 8,3 \\
\hline Czech & 8,3 & 7,9 & 7,1 & 5,3 & 4,4 & 6,7 & 7,3 & 6,7 & 7,0 & 7,0 & 6,1 & 5,7 \\
\hline Slovakia & 18,4 & 16,4 & 13,5 & 11,2 & 9,6 & 12,1 & 14,5 & 13,7 & 14,0 & 14,2 & 13,4 & 11,3 \\
\hline Hungary & 5,8 & 7,3 & 7,4 & 7,3 & 7,7 & 9,7 & 11,2 & 11,0 & 11,0 & 10,4 & 8,1 & 7,3 \\
\hline
\end{tabular}

Source: [15] www.ec.europa.eu (access: 10.08.2019).

The labour markets in V4 countries after joining EU have changed its character, from domestic markets to open market [3]. From year to year an increasing group of employees could choose between activity on the domestic market and legal and illegal (temporary) employment on European markets. This situation usually concerned young people. The potential leave - for a short or longer time - for work on the territory of another EU country have become one of the easily available alternative. The possibility of legal employment abroad has created new work opportunities and had become a potential career path on equal terms. Therefore, research on attitude towards professional work, besides the diagnosis of attitudes towards employment on domestic market, must also include experience and plans for professional work abroad.

\section{Methodology of the research}

The empirical analysis is based on the research, which was conducted in April-May 2015 and November 2016, in four V4 countries - Katowice, Poland (the University of Economics in Katowice, the University of Silesia in Katowice and the Silesian University of Technology), Olomouc and Ostrava, Czech Republic (the Palacky University in Olomouc, the University of Ostrava and the Technical University of Ostrava), Nitra, Slovakia (the Constantine the Philosopher University in Nitra and the Slovak University of Agriculture in Nitra), Godollo, Hungary (the Szent Istvan University in Godollo).

Firstly, a common questionnaire survey was prepared in English and then it was translated into national languages. The questionnaire included 37 extended questions (all the elements of economic awareness) and 10 questions about sociodemographic characteristics. In each of the countries, groups of students were selected to take part in the research using an auditor survey technique. The research was based on the first and second level students from four different types of studies: economics and management, technical, sciences or medical, social studies, humanities. In Poland, 400 surveys were conducted, in the Czech Republic - 400, in Slovakia - 387, and in Hungary - 368. Jointly, 1,555 surveys from four V4 countries were obtained and directed for further analysis.

The article will focus only on answers to questions about attitude towards work. The analysis has been answered in three questions. The first question was as follows: “,Do you think that, after graduating, finding a job in your profession will be easy or difficult?". Students had a possibility to choose one of the option: very easy, rather easy, rather difficult, very difficult, hard to say. The second question was: "Please indicate to what extent you think the following issues are important in life. Please use a scale of 1 to 5, where 1 is not important and 5 - very important.". Only value of work will be subjected to further analysis. The third question was : If you could get a better, permanent job, would you be willing to go abroad? The students were requested to choose such answers as "definitely yes", "rather yes", "rather no", "definitely no", "hard to say". The results will be presented in the tables below. 


\section{Results and discussion}

The research about the diagnosis of attitudes towards work is about to start from the question about the knowledge of future professional work. This knowledge is relevant for placing yourself on the labour market. Students, while choosing course of study, were guided by their own interest and some information about future profession. However, only during studies their knowledge has been more specified. Students mostly could see what their work can be like during apprenticeship. They are able to experience the reality of different types of work and possibilities of future employment when they are working during studies [16]. That is the reason why the following question has been asked: „Do you think that, after graduating, finding a job in your profession will be easy or difficult?". Students had a possibility to choose one of the option: very easy, rather easy, rather difficult, very difficult, hard to say. The table below shows the research results obtained in V4 countries.

Table 2. Finding a job after graduating (\%)

\begin{tabular}{|l|c|c|c|c|c|}
\hline \multicolumn{1}{|c|}{ Answer } & Very easy & Rather easy & $\begin{array}{c}\text { Rather } \\
\text { difficult }\end{array}$ & $\begin{array}{c}\text { Very } \\
\text { difficult }\end{array}$ & Hard to say \\
\hline Poles $(\mathrm{N}=400)$ & 2,8 & 17,0 & 42,5 & 22,8 & 15,0 \\
\hline Czechs $(\mathrm{N}=400)$ & 3,8 & 35,0 & 39,0 & 12,3 & 7,5 \\
\hline Słovaks $(\mathrm{N}=387)$ & 3,4 & 21,2 & 45,5 & 20,2 & 9,8 \\
\hline Hungarians $(\mathrm{N}=369)$ & 4,6 & 32,1 & 47,3 & 6,8 & 9,2 \\
\hline
\end{tabular}

Source: Team research, own calculation

Only small percentage of students in each country think that it is very easy to find a job in their profession. Hungarian students most commonly points out such answer and Polish students the rarest. There are differences in percentage data between examined groups in the answer - rather easy. Mostly chosen by Czechs, almost 1/3 of them chose this answer, then by Hungarians (almost 1/3 of them). More than $21 \%$ of Slovaks thinks that it is rather easy to find a job after graduation and only $17 \%$ of Poles thinks this way. The assessment of employment opportunities after graduation is a result of knowledge students have about the labour market in their country. More or less, it reflects real situation and especially level of unemployment. At the time of the research, the highest rate of unemployment was in Slovakia and then in Poland. There was a difficult labour market in these countries and students were aware of the lack of potential work opportunities [17]. Slightly lower level of unemployment was in Hungary, but the research was carried out in Godollo, which is located about $25 \mathrm{~km}$ from Budapest. It is much easier to find a job in Budapest and that is the reason why the assessment of employment opportunities after graduation is way better. The lowest rate of unemployment is in the Czech Republic, so Czech student although being far from the capital, assess finding a job after graduation most favorably. The assessment of labour market and possibilities of finding a job in their profession will influence on their further attitude towards work.

The research of work value is indicative for affective component. Work was placed among other values. It was similarly done in our research. Young generation, particularly students characterize in a specific value system and that is why set of values was constructed accordingly to this generation. Only value of work will be subjected to further analysis. 
Table 3. Important issues in life - Work (\%)

\begin{tabular}{|l|c|c|c|c|c|}
\hline \multicolumn{1}{|c|}{ Rodzaj odpowiedzi } & $\begin{array}{c}\text { Very } \\
\text { important }\end{array}$ & Important & $\begin{array}{c}\text { Of little } \\
\text { importance }\end{array}$ & $\begin{array}{c}\text { Not } \\
\text { important }\end{array}$ & Hard to say \\
\hline Poles (N =400) & 34,5 & 46,5 & 16,8 & 2,0 & 0,3 \\
\hline Czechs (N =400) & 29,7 & 55,5 & 11,9 & 1,9 & 0,8 \\
\hline Słovaks (N =387) & 34,1 & 45,0 & 14,4 & 1,6 & 4,9 \\
\hline Hungarians (N = 369) & 39,3 & 47,7 & 12,4 & 0,5 & 0,4 \\
\hline
\end{tabular}

Source: Team research, own calculation

The results of research point out that work is the biggest value for Hungarian students (almost $40 \%$ of "very important" answers). It is almost similarly valued by Polish and Slovak students ("very important" answers: Poles - 34,5\%, Slovaks - 34,1\% ) It is the lowest value for Czech students, $29,7 \%$ of them answered: "very important". If we take into consideration answers "important", we can tell that it was most frequently chosen answer by Czech students, then by Hungarian students and almost in equal percentage by Polish and Slovak students. On the other hand, the opposite answer possibility - "of little importance" was most commonly chosen by Polish students, then Slovaks followed by Hungarians and at the end by Czechs. Responses are fluctuating around dozen percent. Differences aren't really essential, but together with "not important" answers we can say that among Polish students are most often people for whom work is unimportant value rather than among Hungarian and then Czech students.

Behavioral component of attitude will be diagnosed by the question about students readiness to go abroad in order to get a better job. Since the research results have shown that it is hard to find a job in own country, maybe going abroad and having a chance to be seen on a global labour marker is a better option. Especially because, as our research show, students during studies are willing to take up a professional work, but it is a job that is incompatible with their education $[18,19]$. Labour market offers series of positions which enable to combine studies with professional work. Some companies, especially services companies, create jobs exclusively for students [20]. However, it is necessary to emphasize that such activity is a difficult task because students need to combine then work with their duties at the university. It can be full-time, part-time or casual work. It helps to improve state of students' budgets and at the same time it allows to gain valuable experience $[21,22$, 23].

Working during studies shows their positive attitude towards it. As our research has shown, students take up work during studies for various reasons [18, 19]. Diversification is most likely due to access to the labour market and employment possibilities. Among Polish students a certain part of them work full-time $(15,0 \%)$, but there is also a significant percentage of students, who don't or have never worked $(40,2 \%)$. They are very polarized in undertaking work [18]. Czech students most often work part-time or they have casual work $(35,8 \%)$. The lowest percentage of them, among all V4 students, don't work $-24,4 \%$ $[18,19]$. Slovak students most commonly work part-time $(42,6 \%)$. A substantial percentage of students don't work according to their qualifications (the highest percentage among V4 students $-57,9 \%$ ). Relatively high percentage of Slovak students work to gain experience. Hungarian students are the one who take up work most commonly among examined V4 students (76,3\%), both during academic year and holidays. Hungarian students most often among others work according to their qualifications $(33,3 \%)[18,19]$.

In terms of students professional future, the attempt of recognising students attitude towards mobility seems to be incredibly interesting - readiness to move to a different city in the country or migration abroad. It shows the attitude towards work. After the accession of the Visegrad Group countries to the EU structures, a period has begun which, from today's perspective, we can call the "golden decade of trans-border mobility" [24]. It is 
difficult not to get the impression that it is coming to an end - we are becoming witnesses of the historical turmoil again, of which Brexit is just as significant as symbolic symptom. The emigration becomes again an uncertain life situation, which is no longer dependent only on one's own preferences, but becomes dependent on unstable and unpredictable political decisions [25].

In this migration context, students were asked: "If you could get a better, permanent job, would you be willing to go abroad?" The table below shows the answers.

Table 4. Students' willingness to mobility to get a better, permanent job (\%)

\begin{tabular}{|l|c|c|c|c|c|}
\hline \multicolumn{1}{|c|}{ Answers } & $\begin{array}{c}\text { Definitely } \\
\text { yes }\end{array}$ & Rather yes & Rather not & $\begin{array}{c}\text { Definitely } \\
\text { not }\end{array}$ & Hard to say \\
\hline Poles $(\mathrm{N}=400)$ & 14,8 & 27,5 & 21,0 & 23,3 & 13,4 \\
\hline Czechs $(\mathrm{N}=400)$ & 14,0 & 30,0 & 37,2 & 12,3 & 6,5 \\
\hline Słovaks $(\mathrm{N}=387)$ & 37,2 & 31,5 & 16,8 & 9,0 & 5,5 \\
\hline Hungarians $(\mathrm{N}=369)$ & 27,8 & 28,3 & 18,5 & 18,5 & 6,9 \\
\hline
\end{tabular}

Source: Team research, own calculation

While analyzing the data we can conclude that students divided into two groups, especially when we take into account the answer: „Definitely yes”. Slovak and Hungarian students are more willing to look for a job on international labour market, while Polish and Czech students are less willing. Slovak students are particularly the most determined (37,2\% of answers - "Definitely yes", and only $9 \%$ - „Definitely not"). When it comes to Slovak students we can explain their high willings for going abroad by the high rate of unemployment. Lack of work perspective in own country encourage students to migrate. Over one quarter of Hungarian students are also totally determined to look for a job abroad. However, decisions on migration of Hungarian students are less understandable. Perhaps they are a result of high assessment of own opportunities on the foreign labour market or these are just political decisions. Only nearly half of the Czech students $(44,0 \%)$ would decide to look for a job abroad and take their chances on the global labour market. Unemployment in the Czech Republic has remained low for years [17]. On the other hand, Polish students, among students from other V4 countries, most commonly answered "Definitely not"( 23,3\%) or they were undecided (13,4\%). In Poland in 2015 and 2016, when the research was carried out, the situation on the labour market started to improve and unemployment was falling [17].

In order to explain other factors that determine the willingness to work abroad, it is necessary to analyze the potential behavior of students in the situation when they have the opportunity to work in the they country, but in the different city (question: „If you could get a better, permanent job, would you be willing to move to another town?"). In the case of Slovakia and Hungary, internal mobility is considered less frequently by students than cross-border movements (definitely yes: $12.7 \%$, yes: $29.5 \%$ ), whereas the foreign migration was in total considered by $68.7 \%$ of the respondents. Similarly, in Hungary, (definitely yes: $12.3 \%$, yes: $31.6 \%$ ), which is a much smaller percentage than of those willing to move abroad (56.1\%) (26). Polish students declare the highest level of internal mobility $(57,8 \%$ rather yes, $17,8 \%$ definitely yes). Only slightly smaller percentage of Czech students chose this option $-53,5 \%$ of respondents is willing to move to different city, while $41,6 \%$ of respondents rejects this option. The willingness to migrate abroad is determined by the possibilities within internal migration and the situation on a national labour market. 


\section{CONCLUSION}

The conducted analysis showed diversed attitudes towards work of students from V4 countries. When we compare individual components of attitudes: cognitive, affective and behavioral, we can distinguish 3 attitudes: coherent, ambivalent and incoherent.

1. Coherent attitude is represented by Slovak students. They assess their national labour market negatively due to the high level of unemployment, at the time when the survey was taken. They also find it hard to find a job connected with their studies. In the case of Slovakia, there are similar difficulties on the labour market in small cities outside Bratyslawa. Smaller markets cannot offer attractive jobs. That is the reason why students are willing to go abroad to find a proper job. That is why, foreign migration for Slovaks students makes more sense.

2. Coherent attitude is also represented by Czechs students. They positively assess their national labour market and they see possibilities to find a job that could be connected with their studies. In the Czech Republic internal migration is chosen by the lowest percentage of student, because the labour market is way easier and unemployment is low. The consequence of this situation is reluctant attitude towards going abroad to look for a job.

3. Ambivalent attitude is represented by Polish students. On the one hand, they negatively assess national labour market and possibilities to find a job connected with their studies. On the other hand, they are not willing to go abroad to look for a job. However, this can be explained by the higher possibility to find a job in a different city. It is due to the fact that Poland is a bigger country than the other three and better job opportunities can be found in bigger cities. Therefore, young people consider internal migration first and then foreign migration.

4. Incoherent attitude is represented by Hungarian students. They positively assess national labour market and possibilities to find a job connected with their studies. The migration outside Budapest (in the case of Hungary) would not make any sense, because the best job opportunities are in the place they live. Despite the good situation on the labour market, a significant number of Hungarian students are willing to go abroad in order to have a better job. Does the reason for this attitude lie on the side of other factors e.g. political?

To sum up, it can be stated that attitudes towards work, especially its behavioral component, are certainly impacted by external factors, such as the assessment of global labour market. However, internal factors play a crucial role. Attitude towards going abroad to look for a job are a result of different situation on the national labour market, it is the rate of unemployment and also the size of the market. This situation especially concerns the analyzed activity on the global labour market.

\section{References}

1. O. Akanle, International migration narratives: Systemic global politics, irregular and return migrations. International Sociology 33, 161-170, (2018)

2. G. Noble, 'It is home but it is not home': habitus, field and the migrant. Journal of Sociology 49, 341-356, (2013).

3. B. Puzio-Wacławik, Spójność ekonomiczno-społeczna krajów grupy Wyszehradzkiej, K. Przybylska (ed.), (Państwowe Wydawnictwo Naukowe, Warszawa, 60-77, 2017)

4. S. D. Witt, Parental influence of children`s socialization and gender roles. Adolescences 32, 253-259, (1997) 
5. J. Dzionek-Kozłowska, S.,N. Rehman, Attitudes of economics and sociology students towards cooperation: cross-structural study. Economics and Sociology 10, 124-136, (2017).

6. L. Manning, P. Parrott, Higher Education, The impact of workplace placement on students' entrepreneurial attitude. Higher Education, Skills and Work-Based Learning 8, 56-69, (2018).

7. J. M. Cucina, K. A. Byle, N. R. Martin, S. T. Peyton, T. F. Gast, Generational differences in workplace attitudes and job satisfaction: Lack of sizable differences across cohorts. Journal of Managerial Psychology 33, 246-264, (2018).

8. F. Znaniecki, W. Thomas, Chłop polski w Europie i Ameryce. (Ludowa Spółdzielnia Wydawnicza, Warszawa, 1976).

9. M. Rokeach M., Beliefs, Attitudes and values. A Theory of Organization and Chang. (Yossey Bass, San Francisco, 1968).

10. S. Ossowski, Z zagadnień psychologii spolecznej. (Państwowe Wydawnictwo Naukowe, Warszawa, 1968).

11. S. Nowak, In: Teorie postaw, (ed.) Nowak S., (Państwowe Wydawnictwo Naukowe, Warszawa, 17-87, 1973).

12. U. Swadźba, In: Managerial trends in the development of enterprises in globalization era, (ed.) I. Kosciarova, Kadekova Z., 868-874. http://spu.fem.uniag.sk/fem/ICoM_2017/files/international_scientific_conference_ico m_2017.pdf., 2017)

13. M. Zieliński, Unemployment and Labor Market Policy in Visegrad Group Countries. Equilibrum-Quartely Journal of Economics and Economic Policy 10, 185-201, (2015).

14. T. Pavelka, T., Long -term unemployment in Visegrad countries. 10 $0^{\text {th }}$ International Days of Statistics and Economics. (Prague, Czech Republic, 1408-1415, 2016).

15. www.ec.europa.eu (access: 10. 08. 2019).

16. E. Hovdhaugen, Working while studying: the impact of term-time employment on dropout rates. Journal of Education and Work 28, 631-651, (2015).

17. M. Trvdoch, Decomposition of Unemployment: The case of the Visegrad group countries. Economie a Management 19, 4-16, (2016).

18. U. Swadźba, In: The economic awareness of the young generation of Visegrad countries. A comparative analysis, (ed.) U. Swadźba, (Wydawnictwo Uniwersytetu Śląskiego, Katowice, 7-101, 2018).

19. U. Swadźba, N. Horakova Hirscher, Values of work in the experience and awareness of the young generation of the Visegrad Countries. Economics and Sociology 12, 177192, (2019).

20. S. P. Vallas, A. Christin, Work and Identity in an Era of Precarious Employment: How Workers Respond to "Personal Branding" Discourse. Work and Occupations 45, 3-3, (2018).

21. N. Hipsz, Komunikat z badań CBOS (132/2014), access: www.cbos.pl (25.07.2019).

22. J. Kalka, Komunikat z badań CBOS (49/2016), access: www.cbos.pl, (25.07.2019).

23. J. Orupabo, Cultural stereotypes and professional self-socialisation in the transition from education to work. Journal of Education and Work 31, 234-246, (2018).

24. R. Cekiera, O pułapkach emigracyjnej lekkości. Doświadczenie tymczasowości w narracjach młodych polskich emigrantów poakcesyjnych, (Wydawnictwo Nomos, Kraków, 2014).

25. R. Cekiera, In: The economic awareness of the young generation of Visegrad countries. A comparative analysis, (ed.) U. Swadźba, (Wydawnictwo Uniwersytetu Śląskiego, Katowice, 102-119, 2018). 